\title{
Human T-lymphotropic virus type 1 p30 interacts with REG $\gamma$ and ATM (Ataxia Telangiectasia Mutated) to promote cell survival
}

\author{
Rajaneesh Anupam ${ }^{1}$, Antara Datta', Nadine Bowden ${ }^{1}$, Nikolozi Shkriabai', Mamuka Kvaratskhelia², \\ Michael Lairmore $3,4,5^{*}$
}

From 15th International Conference on Human Retroviruses: HTLV and Related Viruses

Leuven and Gembloux, Belgium. 5-8 June 2011

Human T cell leukemia virus type 1 (HTLV-1), is complex deltaretrovirus linked to adult T-cell leukemia/lymphoma (ATL) and a variety of immune-mediated disorders. HTLV-1 encodes a nuclear localizing protein, p30, which selectively alters viral and cellular gene expression, activates G2-M cell cycle checkpoints, and is essential for viral spread. p30 interacts with key cellular proteins such as $\mathrm{CBP} / \mathrm{p} 300$ and Myc/TIP60 to differentially modulate host and viral gene expression. We hypothesize that interaction of p30 with host cellular proteins modulates the cellular microenvironment to favor of viral spread. Herein we used immunoprecipitation, affinity pull-down of ectopically expressed p30 coupled with mass spectrometry to identify cellular binding partners of $\mathrm{p} 30$. Our data indicate that p30 specifically binds to cellular ataxia-telangiectasia mutated (ATM) and REG $\gamma$ (a nuclear 20S proteasome activator). In conditions of genotoxic stress p30 expression was associated with reduced levels of ATM and increased cell survival. Knockdown or over expression of REG $\gamma$ paralleled p30 expression suggesting an unexpected enhancement of p30 expression in the presence of REG $\gamma$. Finally, size exclusion chromatography revealed the presence of p30 in a high molecular weight complex along with ATM and REG $\gamma$. Current studies are focused on mapping regions critical for $\mathrm{p} 30-\mathrm{REG} \gamma$ binding and how this interaction may influence HTLV-1 transcription. Based on our findings we propose that HTLV-1 p30 interacts with ATM and REG $\gamma$ to increase viral spread by facilitating cell survival.

\footnotetext{
* Correspondence: lairmore.1@osu.edu

${ }^{3}$ Department of Veterinary Biosciences, The Ohio State University, Columbus, Ohio, 43210, USA

Full list of author information is available at the end of the article
}

\section{Author details}

'Department of Veterinary Biosciences, The Ohio State University, Columbus, Ohio, 43210, USA. ${ }^{2}$ Department of Pharmaceutics, College of Pharmacy, The Ohio State University, Columbus, Ohio, 43210, USA. ${ }^{3}$ Department of Veterinary Biosciences, The Ohio State University, Columbus, Ohio, 43210, USA. ${ }^{4}$ Center for Retrovirus Research, The Ohio State University, Columbus, Ohio, 43210, USA. ${ }^{5}$ Comprehensive Cancer Center, Arthur G. James Cancer Hospital and Solove Research Institute, The Ohio State University, Columbus, Ohio, 43210, USA.

Published: 6 June 2011

doi:10.1186/1742-4690-8-S1-A202

Cite this article as: Anupam et al:: Human T-lymphotropic virus type 1 p30 interacts with REG $\gamma$ and ATM (Ataxia Telangiectasia Mutated) to promote cell survival. Retrovirology 2011 8(Suppl 1):A202.
Submit your next manuscript to BioMed Central and take full advantage of:

- Convenient online submission

- Thorough peer review

- No space constraints or color figure charges

- Immediate publication on acceptance

- Inclusion in PubMed, CAS, Scopus and Google Scholar

- Research which is freely available for redistribution

Submit your manuscript at www.biomedcentral.com/submit
C Biomed Central
C Biomed Central

(C) 2011 Anupam et al; licensee BioMed Central Ltd. This is an open access article distributed under the terms of the Creative Commons Attribution License (http://creativecommons.org/licenses/by/2.0), which permits unrestricted use, distribution, and reproduction in any medium, provided the original work is properly cited. 